\title{
Corners, Tables, Lines
}

\section{Towards a Diagrammatics of Race}

\author{
Staffan Müller-Wille | ORCID: 0000-0003-4929-8373 \\ Department of History and Philosophy of Science, University of Cambridge, \\ Cambridge, UK \\ sewm3@cam.ac.uk
}

\begin{abstract}
The modern concept of race is usually traced back to proponents of a "natural history of mankind" in the European Enlightenment. Starting from allegorical representations of the four continents in the late sixteenth and seventeenth centuries and the eighteenthcentury visual genre of castas paintings, I suggest that modern conceptions of race were significantly shaped by diagrammatic representations of human diversity that allowed for tabulation of data, combinatorial analysis, and quantification, and hence functioned as "tools to think with." Accounting for racial ancestry in terms of "proportions of blood" not only became a preoccupation of scholars as a consequence, but also came to underwrite administrative practices and popular discourses. To contribute to a better understanding of the history of race relations, historians of the race concept need to pay more attention to these diagrammatic aspects of the concept.
\end{abstract}

\section{Keywords}

history of race concept - diagrams - continents

The concept of race certainly belongs to one of the most contentious and historically fraught concepts in the human sciences. This is reflected by the curious fact that its history has mostly been written as the history of a fatal misconception, or the false idea that human races exist in nature and are amenable, as any other natural object, to scientific description, analysis and explanation. The historiographical consensus of the bulk of available literature is therefore 
that race was invented, not discovered, by enlightenment naturalists like Carl Linnaeus, Georges Buffon or Johan Friedrich Blumenbach. ${ }^{1}$

This prevailing view, to be sure, does not simply get history wrong. As I have argued elsewhere, it rather misses what one could call, with Foucault and for the lack of a better word, the "positivity" of the race discourse. Scientific concepts do, as a rule, not simply reflect a nature "out there," as in a mirror, but are designed to connect things in new ways. Their function is pragmatic and transformative - to see things in ways that usually do not present themselves spontaneously. This is especially true of taxonomic concepts like race, which tend to bring together things that are precisely not juxtaposed by nature. The power that the race concept possesses in shaping the goals and actions of political movements - a power that endures to this very day — cannot be grasped without conceding that this power, in part at least, resides in the historically tenacious set of discursive rules by which it operates. ${ }^{2}$

In this article, which is more of a short essay than a full research article, I want to draw attention to a largely neglected aspect of the history of the race concept, namely the role that diagrams have played in its articulation alongside texts and pictorial representations. In this, I will be taking both "race" and "diagram" in their broadest possible meanings. Recent scholarship on the history of the race concept has emphasized that not every taxonomic subdivision of the human species constitutes a division by race, and that the concept of race was introduced by naturalists like Buffon in the eighteenth century to refer much more specifically to heritable varieties. ${ }^{3}$ While this is true, it does not entail that taxonomies of humankind were irrelevant for the history of the race concept, nor that other phenomena than hereditary variation, such as race

1 For a recent, powerful exposition of this view, see Jonathan Marks, Is Science Racist? (Cambridge: Polity Press, 2017), chap. 2. Here, and throughout this article, I am talking about the history of the concept of race. The history of race and racism has been investigated in a much more "positivistic" vein, that is, with the explicit recognition that race is a socio-political reality that informs and in turn is informed by this concept; see Marius Turda and Maria Sophia Quine, Historicizing Race: A Global History (London: Bloomsbury Publishing, 2018).

2 Staffan Müller-Wille, "Race and History: Comments from an Epistemological Point of View," Science Technology and Human Values 39 (2014): 597-6o6. On positivity, see Michel Foucault, Archaeology of Knowledge, trans. Alan Mark Sheridan Smith (Hoboken: Taylor and Francis, 2002), 125. On the tenacity of racial discourse in the twentieth century, see Claudio Pogliano, L'ossessione della razza. Antropologia e genetica nel xx secolo (Pisa: Edizioni della Normale, 2005).

3 Claude-Olivier Doron, L'homme altéré: Races et dégénérescence (Ceyzérieux: Champ Vallon, 2016); Staffan Müller-Wille, "Reproducing Difference: Race and Heredity from a Longue Durée Perspective," in Race, Gender and Reproduction: Philosophy and the Early Life Sciences in Context, ed. Suzanne Lettow (New York: suny Press, 2014), 217-235. 
mixture, did not play a role in articulations of the race concept. Understanding race as strictly referring to hereditary varieties only blocks the view for important connections.

Similar reasons motivate me to understand diagrams broadly. Diagrams have played a key role in the sciences ever since their inception, yet it is only recently that this role has become a subject of comparative analysis in its own right. ${ }^{4}$ Hybridizing text, image and calculation, diagrams often fall into a gap left by the visual turn in the history of science. Diagrams, as Charlotte Bigg puts it, "are not usually thought of as images since they do not follow realistic conventions of representation but rather aim to portray relations, to manipulate numbers and other entities, or to organize, display and communicate information." 5 Portraying relations is something that a painting, or a table, can do as well, of course, so in this sense, every visual representation exhibits diagrammatic aspects. What distinguishes diagrams according to this broad understanding is their function; they serve as tools to think with, or rather, following Charles Sanders Peirce, diagrams mediate thought and action. "The truth," as Peirce reasoned,

appears to be that all deductive reasoning, even simple syllogism, involves an element of observation; namely, deduction consists in constructing an icon or diagram the relations of whose parts shall present a complete analogy with those of the parts of the object of reasoning, of experimenting upon this image in the imagination, and of observing the result so as to discover unnoticed and hidden relations among the parts. ${ }^{6}$

There is a small, but exquisite body of literature on the role of diagrams as "tools for thinking" in the history of various disciplines, such as Ursula Klein's study of Berzelian formulas, David Kaiser's book on Feynmann diagrams, Matthew Eddy on diagrams in eighteenth-century chemistry, or the edited collections by Sachiko Kusukawa and Ian Maclean as well as Nick Jardine and Isla Fay that focus on mathematics, astronomy, mechanics and medicine. ${ }^{7}$ In the life sci-

4 Alexis Smets and Christoph Lüthy, "Words, Lines, Diagrams, Images: Towards a History of Scientific Imagery," Early Science and Medicine 14 (2009): 398-439.

5 Charlotte Bigg, "Diagrams," in A Companion to the History of Science, ed. Bernard Lightman (Hoboken, NJ: John Wiley \& Sons, 2016), 557.

6 Charles S. Peirce, "On the Algebra of Logic: A Contribution to the Philosophy of Notation," American Journal of Mathematics 7 (1885): 182.

7 Ursula Klein, "Paper Tools in Experimental Cultures," Studies in the History and Philosophy of Science 32 (2001): 265-302; David Kaiser, Drawing Theories Apart: The Dispersion of Feynman Diagrams in Postwar Physics (Chicago: University of Chicago Press, 20o9); Matthew Daniel 
ences, there has been a surge of publications in the last decade on series, trees and networks as fundamental forms of diagrammatic reasoning or "canonical icons," as Stephen Jay Gould called them in a foundational article. ${ }^{8}$ I am going to build on this literature in the following, but with two distinct methodological twists. First, rather than trying to reduce particular diagrammatic forms like the tree to one fundamental meaning, I suggest to remain open about the possibility that they may be read in a plurality of ways. ${ }^{9}$ The medieval "Tree of Porphyry," for example, which many scholars have located at the origin of a "Western," hierarchical way of looking at nature and society, was to be read from top to bottom and asymmetrically. ${ }^{10}$ And second, rather than solely focussing on diagrams illustrating racial taxonomies, I suggest to also look at how race was (re-)configured in genealogical diagrams depicting relations among individuals. In this broader sense of "diagrams of relatedness," racial diagrams reveal themselves as serving the purpose of concretely locating oneself and others in a system of identities and alliances. With this two-fold twist, I suggest, it is possible to go beyond the history of a particular "icon," and achieve a comparative analysis of how diagrams of relatedness not only supported epistemic and cultural, but also political practices. Race is a particularly interesting concept in

Eddy, "How to See a Diagram: A Visual Anthropology of Chemical Affinity," Osiris 29 (2014): 178-196; Sachiko Kusukawa and Ian Maclean, eds., Transmitting Knowledge: Words, Images, and Instruments in Early Modern Europe (Oxford: Oxford University Press, 2006); Nicholas Jardine and Isla Fay, eds., Observing the World through Images: Diagrams and Figures in the Early-Modern Arts and Sciences (Leiden: Brill, 2013).

8 Stephen Jay Gould, "Redrafting the Tree of Life," Proceedings of the American Philosophical Society 141 (1997): 30. For a classic account, see Giulio Barsanti, La scala, la mappa, l'albero. Immagini e classificazioni della natura fra sei e ottocento (Firenze: Sansoni, 1992). For a recent review of the literature, see Petter Hellström, Trees of Knowledge: Science and the Shape of Genealogy (Uppsala: Acta Universitatis Upsaliensis, 2019), chap. 1.

I am following an approach developed together with Caroline Arni, Marianne Sommer and Simon Teuscher; see "In the Shadow of the Tree: The Diagrammatics of Relatedness as Scientific, Scholarly, and Popular Practice (Sinergia)," Universität Luzern, https://www .unilu.ch/index.php?id=9oo6\&L=1, accessed August 10, 2021.

10 Annemieke R. Verboon, "The Medieval Tree of Porphyry: An Organic Structure of Logic," in The Tree: Symbol, Allegory, and Mnemonic Device in Medieval Art and Thought, ed. Pippa Salonius and Andrea Worm, International Medieval Research, Vol. 20 (Turnhout: Brepols Publishers, 2014), 105. "The tree metaphor," as the author concludes, "is, overall, not a very consistent image for the Tree of Porphyry" - or rather, it is, if one only takes into account that arbor in Latin (just as arbre in French) not only refers to trees, but also to beams, timber and woodwork, or things made from trees. For a discussion of the Tree of Porphyry as shaping Western thinking, see Nathalie Gontier, "Depicting the Tree of Life: The Philosophical and Historical Roots of Evolutionary Tree Diagrams," Evolution: Education and Outreach 4 (2011): 515-538. 


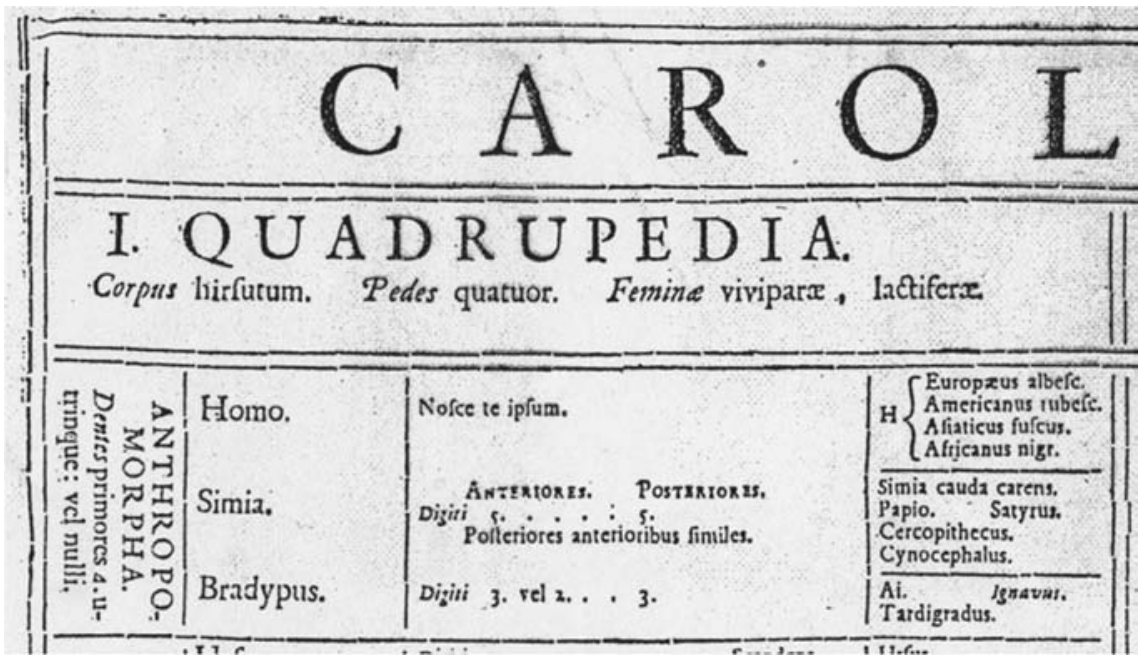

FIGURE 1 Carl Linnaeus's classification of four human "varieties" in Systema naturae (Leiden: Theodor Haak)

WIKIMEDIA COMMONS, HTTPS://COMMONS.WIKIMEDIA.ORG

this respect because its articulation in diagrams, as I hope to show in the following by drawing on a few examples, offered entry points for political interference on the level of both populations and family affairs.

Race as we know it indeed seems to have been invented. In 1735, Linnaeus listed four human "varieties" in Systema naturae, based on an obviously fanciful classification by skin colour: "whitish Europeans, reddish Americans, tawny Asians and blackish Africans" (Europeeus albesc. Americanus rubesc. Asiaticus fuscus. Africanus nigr.; see Fig. 1). Complexion played an important role in medical diagnostics and physiognomy long before the eighteenth century, and was sometimes linked to geography and inheritance. ${ }^{11}$ But the idea that skin colour alone could serve as the basis for a disjunctive and exhaustive classification of the human species was new. In fact, if one tries to ascertain the authorities from which Linnaeus's classification might have flown, only a trickle of textual sources emerges. His proposal of a four-fold classification of mankind presents a clear case of "counter-induction," based as it was on no good empirical evidence at all, be it first-hand or second-hand. ${ }^{12}$

11 Maaike van der Lugt, "La peau noire dans la science médiévale," in La pelle umana, ed. Claudio Leonardi, Micrologus 13 (Florence: SISMEL edizioni, 2005), 439-475.

12 Staffan Müller-Wille, "Linnaeus and the Four Corners of the World," in The Cultural Politics of Blood, 1500-1900, ed. Kimberly Anne Coles, Ralph Bauer, Zita Nunes, and Carla L. Petersen (London: Palgrave Macmillan, 2015), 191-209. 
This argument neglects possible visual sources, however. In addition to physical traits, for example, Linnaeus's classification scheme relied on the geographic division of (at the time) four continents, for which there existed a long-standing visual tradition. A good example from this tradition is Andrea Pozzo's spectacular ceiling fresco Triumph of St. Ignatius of Loyola, completed in 1685 for the church Sant-Ignazio in Rome. The painting contains four allegorical groups that represent the four continents through female figures of distinct complexions, each of them associated with an animal-Europe with a horse, America with a puma, Asia with a camel, and Africa with a crocodileand additionally distinguished by garments and insignia. While Pozzo's ceiling fresco is not a diagram, the arrangement of the four groups in the corners of an imaginary building opening up into the sky for the viewer beneath it brings in a diagrammatic aspect (see Fig. 2). Its open, tabular structure departs strikingly from the more closed, organic structure of medieval mappae-mundi, also known as $\mathrm{T}$ and $\mathrm{O}$ maps, that aligned the three world parts with the cross and the body of Christ, and associated them with the sons of Noah, Shem, Japhet and Ham. ${ }^{13}$ In contrast to this, the relation of the personifications of the four continents to each other on Pozzo's fresco is abstract and devoid of any physical connection. What unites them is rather their common relation in a near-level field of spiritual dominion, centred on the figure of Ignatius of Loyola. Pozzo was himself a Jesuit, and worked with an imagery that was well-established within the propaganda of the Society of Jesus. ${ }^{14}$

Linnaeus, of course, was never in Rome to see Pozzo's painting. But allegorical representations of the four continents, by the time he began to publish, had become an omnipresent element of European culture - not only in the form of lavish paintings filling churches and eventually palaces, but also in the more everyday form of tiles, figurines, or trinkets. The arrangement of four human "varieties" in Systema naturae in a simple list exhibits a striking structural resemblance with the way in which these popular representations portray the four continents, and their inhabitants, as essentially distinct and separate entities. ${ }^{15}$ In his own field of expertise, botany, Linnaeus contributed himself to the

\footnotetext{
13 Jerry Brotton, Trading Territories: Mapping the Early Modern World (New York: Reaktion Books, 1997), 28-30.

14 Bernhard Kerber, “'Ignem Veni Mittere in Terram.' A proposito dell' iconografia della volta di S. Ignazio," in Artifizi della metafora. Saggi su Andrea Pozzo, ed. Richard Bösel and Silvia Salviucci Insolera (Rome: Artemide, 2011), 81-91.

15 David Bindman, Ape to Apollo: Aesthetics and the Idea of Race in the 18th Century (London: Reaktion Books, 2002), 24-28. On the striking presence of the four continents in seventeenth and eighteenth century courtly and bourgeois culture, see Wolfgang Schmale, Marion Romberg, and Josef Köstlbauer, eds., The Language of Continent Allegories in Baroque
} 


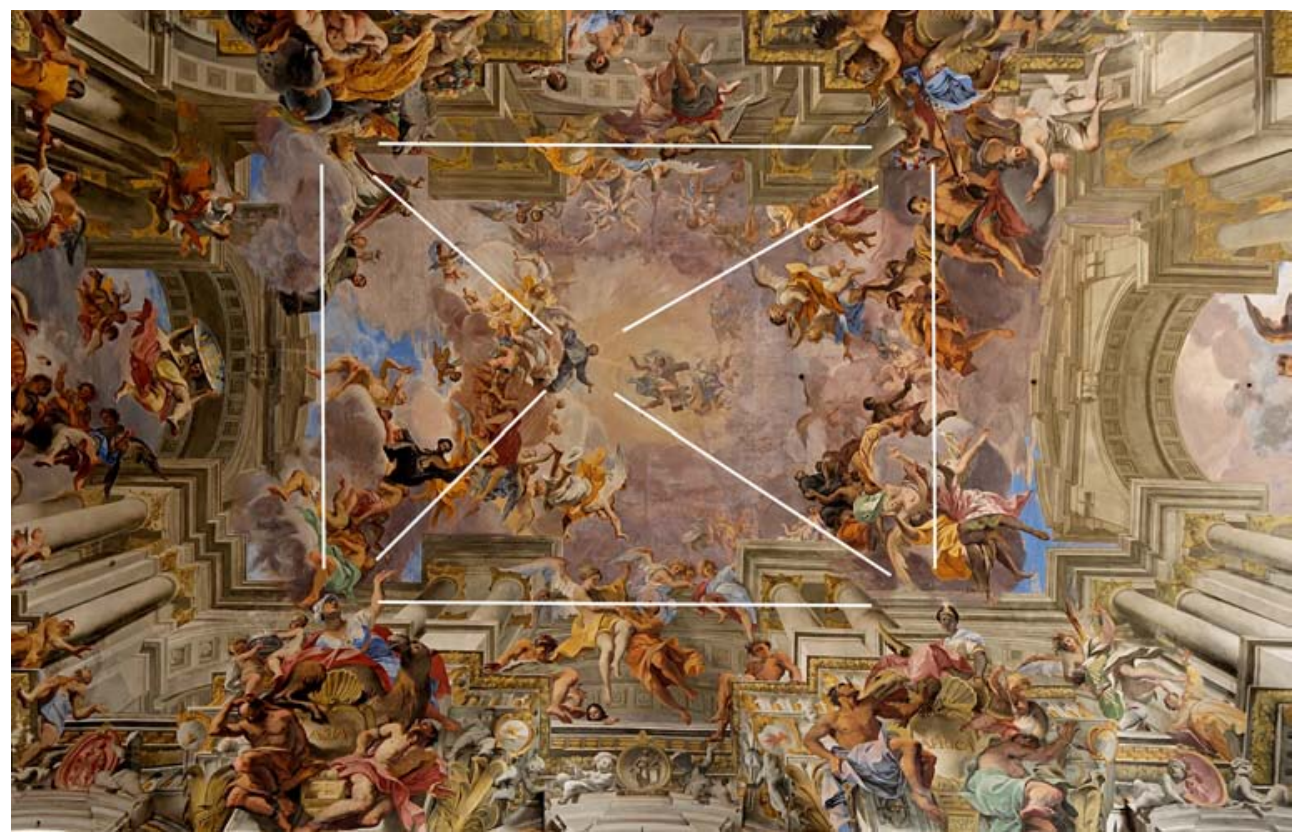

FIgURE 2 Andrea Pozzo, Gloria di Sant'Ignazio (1685), ceiling fresco in Sant'Ignazio, Rome. Lines added to connect the allegorical representations of four continents with Ignatius of Loyola in the centre left of the painting MODIFIED FROM WIKIMEDIA COMMONS, HTTPS://COMMONS.WIKIMEDIA.ORG

perpetuation and transformation of this popular genre with the frontispiece to Hortus cliffortianus (1737). Whereas the frontispiece of John Parkinson's Theatrum botanicum (1640) showed the four continents in the static, tabular and seemingly equitable arrangement that we also saw in Pozzo, Linnaeus's frontispiece to Hortus cliffortianus depicted a more dynamic situation, with Europe reigning over the three other continents, and Africa, while standing upright, occupying the background of the two figures of Asia and America who are bowing or kneeling in front of Europe to offer her their plants (see Fig. 3 and 4). The field that seemed so even in Parkinson and Pozzo has been replaced by a field of uneven geopolitical forces. In this sense, Linnaeus's list of four human "varieties" can be read as a scale or series clearly articulating a descending hierarchy of worth and power, with Europeans at the top and Africans at the bottom, and

Central Europe (Stuttgart: Franz Steiner Verlag, 2016), and Maryanne Cline Horowitz and Louise Arizzoli, eds., Bodies and Maps:Early Modern Personifications of the Continents (Leiden: Brill, 2020). 


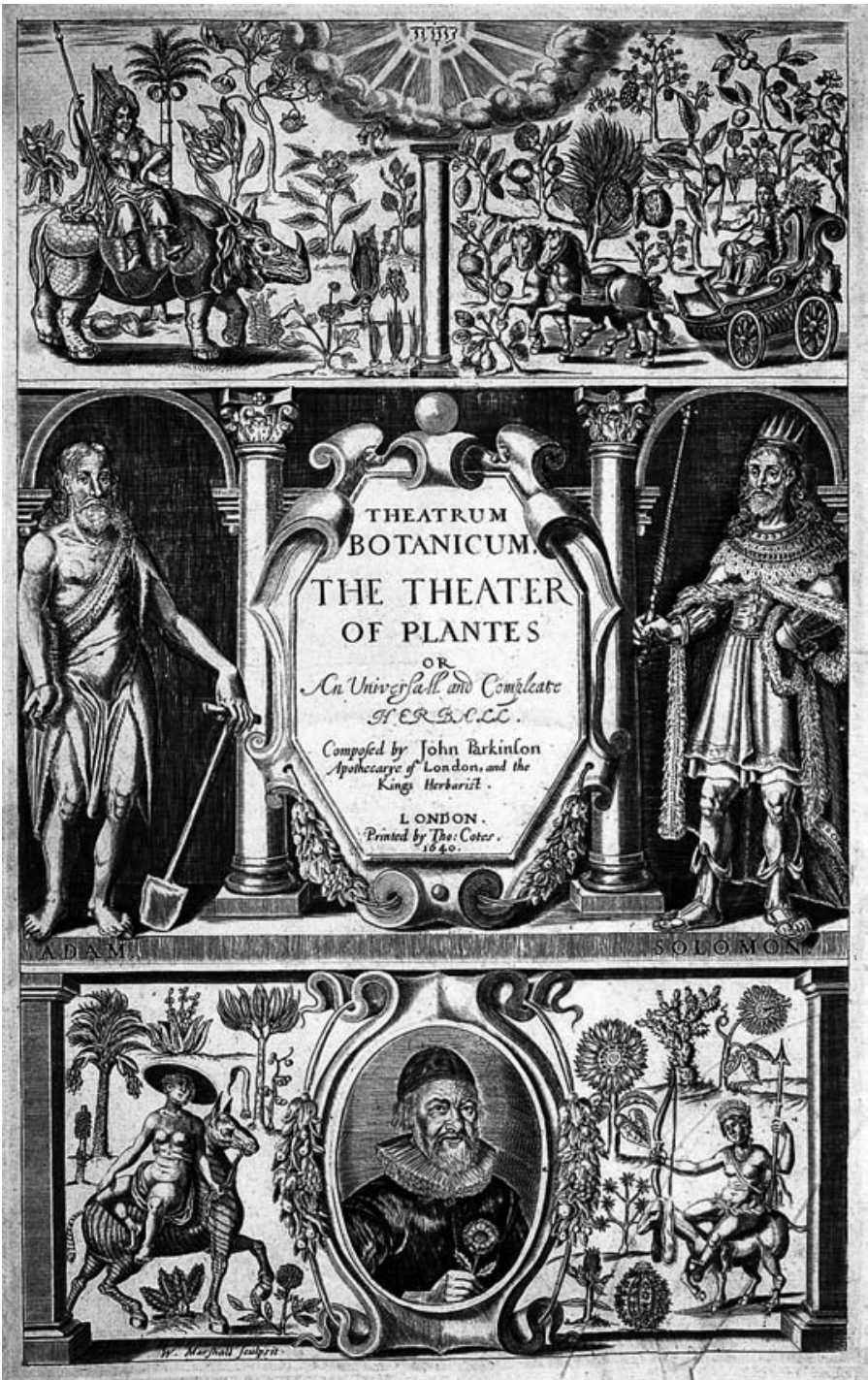

FIGURE 3 Frontispiece of John Parkinson, Theatrum Botanicum = The Theater of Plantes or, an Herball of large extent (London: Tho., Cotes, 1640)

WIKIMEDIA COMMONS, HTTPS://COMMONS.WIKIMEDIA .ORG 


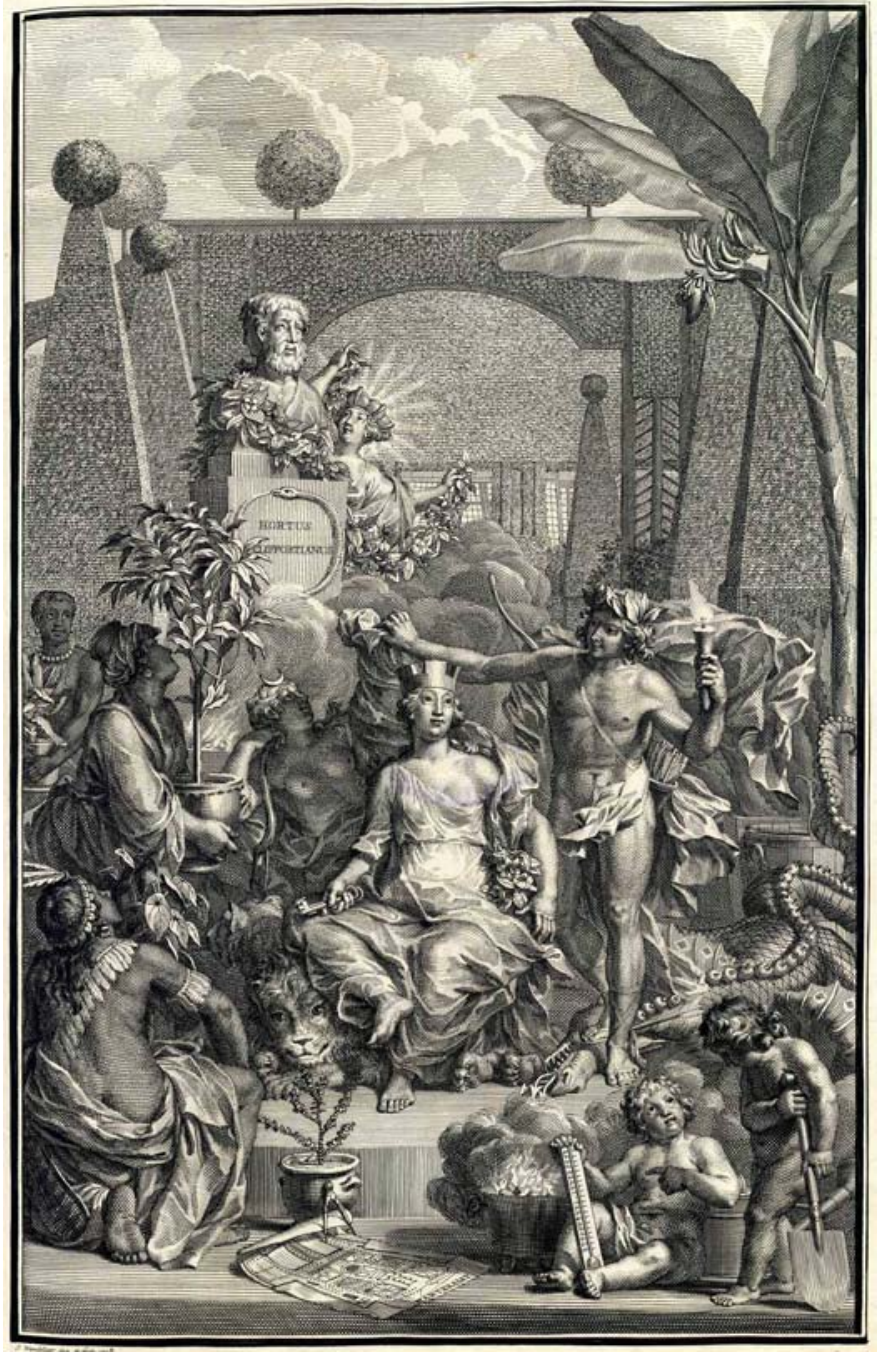

FIGURE 4 Frontispiece of Carl Linnaeus, Hortus Cliffortianus (Amsterdam:n. p., 1737)

WIKIMEDIA COMMONS, HTTPS://COMMONS.WIKIMEDIA .ORG 
this is also how Linnaeus further developed his initial classification in later editions of Systema naturae. ${ }^{16}$

That Linnaeus's presentation of human races in the first edition of Systema naturae can also be read as a hierarchy, should not detract from its status as a simple table correlating geographic origin and skin colour and presenting its subjects as essentially independent entities. Another visual genre depicting race relations, emerging from eighteenth century Mexico and Spain, can illustrate this further, while at the same time revealing the potential for combinatorial and calculational operations that tabular arrangements offer. In oilpaintings collectively known as Las Castas, race mixture was presented in a chequered arrangement of individual images, each of them showing a husband and wife of differing racial ancestry or casta, together with their "mixed" offspring (see Fig. 5). Garments, utensils and the situation in which the family was shown formed visual narratives that were aesthetically pleasing but also transported moral and political messages about the dangers of miscegenation. But the underlying combinatorial logic was rigid, as emphasized by the visual arrangement and short explanatory sentences added to each individual image: Español con India Mestizo, Mestizo con Española Castizo, [...], Español con Mora Mulato, Mulato con Española Morisco, and so forth.

These paintings, it should be noted, were produced for colonial and metropolitan elites. Although casta was related to status-Europeans and "Indios," in contrast to "Blacks," were protected from slavery, and allowed to own landthe castas paintings neither reflected a social reality of strict racial order in the Spanish colonies (on the ground, casta categories proved extremely fluid), nor were they a spontaneous expression of folk beliefs. Rather, they seem to have satisfied a fascination of European and colonial elites with the wealth of diversity produced from simple combination. ${ }^{17}$ The underlying combinatorial principle became even more pronounced through its translation from

16 On the motif of four continents and racial hierarchy, see Francisco Bethencourt, Racisms: From the Crusades to the Twentieth Century (Princeton: Princeton University Press, 2013), $65^{-82}$. On the interplay between the "European colonial enterprise" and visualisations of race in eighteenth-century natural history, see Snait B. Gissis, "Visualizing 'Race' in the Eighteenth Century," Historical Studies in the Natural Sciences 41 (2011): 41-103. For a succinct presentation of Linnaeus's elaboration of the racial hierarchy in later editions of Systema naturae, see Isabelle Charmantier, "Linnaeus and Race," Linnean Society of London, https://www.linnean.org/learning/who-was-linnaeus/linnaeus-and-race, accessed June 28, 2021.

17 Rebecca Earle, "The Pleasures of Taxonomy: Casta Paintings, Classification, and Colonialism," The William and Mary Quarterly 73 (2016): 427-466. 


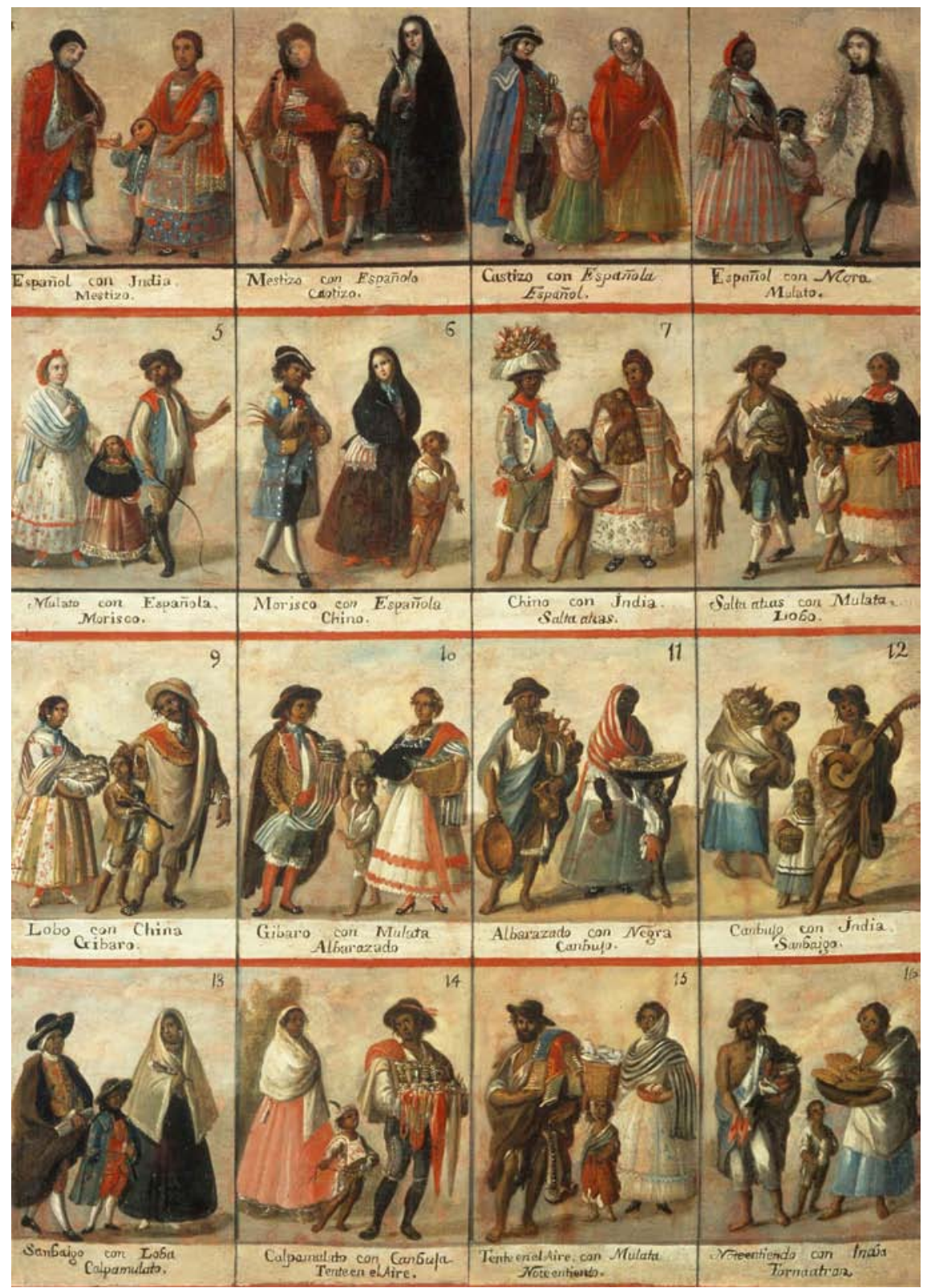

FIGURE 5 Casta paitning. Unknown artist. Oil on canvas. Museo Nacional del Virreinato, Tepotzotlan, Mexico WIKIMEDIA COMMONS, HTTPS://COMMONS.WIKIMEDIA.ORG 
images into diagrams adorning scholarly texts. ${ }^{18}$ Not only was it highlighted by typographical layout as well as dotted and straight lines, but also expressed in mathematical form. The Jesuit Joseph Gumilla, one of the first to bring the castas system to the attention of European scholars in his natural history of the Orinoco region, integrated such a diagram in his discussion of "whitening" (blanquèar). As Gumilla explained (see Fig. 6), through repeated marriage with a "European," the descendants of a "Black woman" (Negra) could pass through various stages of mixture, named Mulata, Quarterona, and Ochavòna, to end up in a Puchuela, who was "entirely white" (Blanca totalmente). Next to these terms, he stated the corresponding mixing ratios, derived from the assumption that both parents contribute equally to the generation of a child. Rather awkwardly, but probably in order to align the ratios with the names, Gumilla thus states that a Mulata receives "two quarters from each parent," a Quarterona "a quarter from the Mulata," and an Ochavòna "one eighth from the Mulata." The text then goes on to explain that a Puchuela, who goes on to marry a Mulato or Negro respectively, initiates an inverse process of "receding" (retroceder) or "backing off" (attrassar) from the status of "pure whites" (puros blancos).${ }^{19}$ The attraction that this scheme exerted on the scholarly imagination becomes clear, when we see that, almost seven decades later, Alexander von Humboldt included a similar diagram in his Essay politique sur le royaume Nouvelle Espagne (1811) (see Fig. 7), despite his critical attitude towards the idea that "a more or less white skin decides on the rank that a human being occupies in society." 20

Humboldt's account is also remarkable because he admits that the "fractions of blood" ( fractions du sang) assigned to different castes are derived from "principles sanctioned by custom" (principes sanctionnés par l'usage). Indeed, the various theories of generation that prevailed until the advent of cell theory in the mid-nineteenth century usually assumed that male and female contributions to the constitution of the offspring were everything else but equal. ${ }^{21}$ The

18 On the following, see Renato G. Mazzolini, "Las Castas: Inter-Racial Crossing and Social Structure (1770-1835)," in Heredity Produced. At the Crossroads of Biology, Politics and Culture, 1500-1870, ed. Staffan Müller-Wille and Hans-Jörg Rheinberger (Cambridge, Mass.: MIT Press, 2007).

19 Joseph Gumilla, El Orinoco ilustrado y defendido, historia natural, civily geographica de este gran rio y de sus caudalosas vertientes, 2nd ed. (Madrid: Manuel Fernandez, 1745), 86.

20 Alexander von Humboldt, Essai politique sur le royaume de la Nouvelle-Espagne, Voyage de Humboldt et Bonpland, Troisième Partie, Tome Premier, 5 vols. (Paris: F. Schoell, 1811), vol. $2,5^{-}{ }^{2}$.

21 Florence Vienne, "Eggs and Sperms as Germ Cells," in Reproduction: Antiquity to the Present Day, ed. Lauren Kassell, Nick Hopwood, and Rebecca Flemming (Cambridge: Cambridge University Press, 2018), 413-426. 


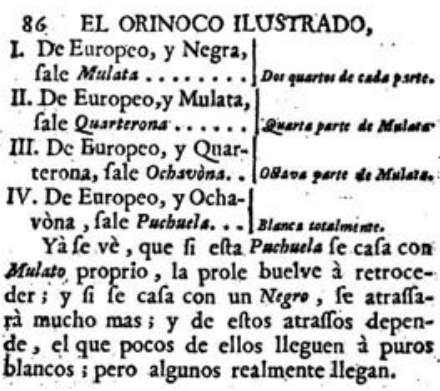

\section{FIGURE 6}

Extract from Joseph Gumilla, El Orinoco ilustrado y defendido, historia natural, civil y geographica de este gran rio y de sus caudalosas vertientes, nd ed. (Madrid: Manuel Fernandez, 1745) GOOGLE BOOKS, HTTPS://BOOKS.GOOGLE.COM/

\section{Castes. Mélange dusang. \\ Quarterons, $\frac{1}{4}$ nègre $\frac{1}{4}$ blanc. \\ Quinterons, $\div$ nègre $\div$ blanc. \\ Zambos, $\quad \frac{1}{4}$ nègre $\div$ blanc. \\ Zambos prietos, $\frac{\tau}{\tau}$ nègre $\div$ blanc.}

Il arrive souvent que des familles qui sont soupçonnées d'être de sang mêlé, demandent à la haute-cour de justice (1'Audiencia) qu'on les déclare appartenir aux blancs. Ces déclarations ne sont pas tovjours conformes au jugement des sens. On voit des mulätres trèsbasanés qui ont eul'adresse de se faire Blanchir (c'est l'expression ban, 'e du peuple). Quand

\section{FIGURE 7}

Extract from Alexander von Humboldt, Essai politique sur le royaume de la Nouvelle-Espagne (Paris: F. Schoell, 1811) BIODIVERSITY HERITAGE LIBRARY, WWW.BIODIVERSITY LIBRARY.ORG

simple formula that each parent contributes half nevertheless proved to be of astonishing continuity and versatility. Data sheets preserved from anthropometric surveys of Native Americans that the German-American anthropologist Franz Boas carried out in 1891 and 1892 provide a good example. They begin with a section that provides personal information on the subject measured, including his or her "tribe," as well as "tribe of father" and "tribe of mother." Entries in these fields often reveal mixed descent, expressed in numerical proportions that sometimes retrace racial ancestry to the generation of great grandparents. Boas used this information to build complex, statistical arguments about segregation and hereditary predominance of certain racial traits (see Fig. 7). Thus he tried to demonstrate that the "Indian type" possessed a "greater influence," or "hereditary force" (Vererbungskraft), on the "mixed race" (Mischrasse) with respect to certain traits than whites by tabulating physical measurements for "full-", “3/4-" and “3/8-blood" native Americans. ${ }^{22}$

22 Franz Boas, "Zur Anthropologie der nordamerikanischen Indianer," Zeitschrift für Ethnologie 27 (1895): 366-411. On Boas's anthropometric studies, which were foundational for the critique of typological race concepts in the twentieth century, see Staffan Müller-Wille, "Data, Meta Data and Pattern Data: How Franz Boas Mobilized Anthropometric Data, 1890 and Beyond," in Data Journeys in the Sciences, ed. Sabina Leonelli and Niccolò Tempini (Cham: Springer International Publishing, 2020), 265-283. 


\begin{tabular}{|c|c|c|c|}
\hline$=$ & $\begin{array}{c}\text { Vollbhut } \\
157\end{array}$ & $\begin{array}{c}\% \text {. Blut } \\
85\end{array}$ & $\begin{array}{c}\% \text { \% Blut } \\
73\end{array}$ \\
\hline $124-125 \ldots \ldots$ & 0,4 & - & - \\
\hline $196-129 \ldots \ldots$ & 0,2 & - & - \\
\hline $128-129 . .$. & - & - & - \\
\hline $130-131 \ldots \ldots$ & - & - & - \\
\hline $182-183 \ldots \ldots$ & - & - & 0,9 \\
\hline $184-185 \ldots \ldots$ & 1.1 & 0,8 & 1,4 \\
\hline $158-187 \ldots \ldots$ & 2,8 & 28 & 3,7 \\
\hline $138-129 \ldots .$. & 4,4 & 7,2 & 7,3 \\
\hline $140-141 \ldots \ldots$ & 8,8 & 6 & 12,8 \\
\hline $142-143 \ldots$ & 8,9 & 6,7 & 90,1 \\
\hline $144-145 \ldots \ldots$ & 12,6 & 2,1 & 14,2 \\
\hline $146-147 \ldots$ & its 3 & 13,9 & 11,4 \\
\hline $148-149 \ldots \ldots$ & $14, a$ & 16,3 & 8,7 \\
\hline $150-151 \ldots \ldots$ & 11,2 & 16,3 & 10,0 \\
\hline $152-153 \ldots$. & 6,4 & 2,9 & $a, 2$ \\
\hline $164-155 \ldots \ldots$ & a & 7,1 & 1,4 \\
\hline $156-152 \ldots \ldots$ & 6,6 & 1,2 & 1,4 \\
\hline $168-159 \ldots .$. & 36 & e, & 0,9 \\
\hline $160-161 \ldots \ldots$ & 0,6 & 1,6 & - \\
\hline $162-163 . .$. & - & 0,4 & - \\
\hline $164-160 \ldots \ldots$ & 24 & - & - \\
\hline $166-167 \ldots \ldots$ & 0,2 & - & - \\
\hline
\end{tabular}

FIGURE 8

Table from Franz Boas, "Zur Anthropologie der nordamerikanischen Indianer." Zeitschrift für Ethnologie 27 (1895): 410

WWW.JSTOR.ORG

In the case of Boas, there is good evidence that the accounts of racial ancestry in terms of proportions of "blood" where not imposed by the observer, but provided by the study's subjects. Boas, in other words, relied on selfidentification, a practice that is common to this day in most statistical studies that use race as a "proxy" for genetic differences. That he could do so is hardly surprising, given the fact that the 189 o US census also asked to determine whether one was "white, black, mulatto, quadroon, octeroon, Chinese, Japanese, or Indian," and given the significance that "purity of blood" was gaining in the USA in the context of racial segregation, not only of black and white Americans, but native Americans as well. ${ }^{23}$ One can safely assume that, by the end of the nineteenth century, accounting for one's race in terms of a simple arithmetic calculation of ancestral contributions had become a near-global practice.

From the examples presented in the preceding, one might draw the conclusion that science, more often than not, is driven from behind, that is, that it finds its objects and fields of enquiry already shaped by cultural forces. The aim of this essay is not, however, revision, neither on the level of established grand narratives, nor on the more local level of the work of the individual scholars and scientists mentioned in the preceding. By sketching out a few examples, I rather wanted to point out that a history of race as a concept is richer than one might expect and that diagrammatic representations played a crucial role in its articulation. This does not mean that an analysis of the diagrammatic aspects

23 Jennifer L. Hochschild and Brenna Marea Powell, "Racial Reorganization and the United States Census 1850-1930: Mulattoes, Half-Breeds, Mixed Parentage, Hindoos, and the Mexican Race," Studies in American Political Development 22 (2008): 59-96. 
of visual representations of race is already sufficient to explain the evolution of the concept. But I hope to have shown that it can at least open up new and fruitful directions of research and that, conversely, the history of a concept cannot be reduced to a history of its explicit definitions. In the case of the race concept, such a history would actually be a history of evident, and often selfadmitted, failure. Like every important concept in the history of science, the race concept did not gain its power through rigid definition but rather through the manipulations - tabulations, permutations, and calculations - it enabled, not only in the scholar's head or study, but in wider society as well. With Foucault (and Deleuze), I maintain that such power of concepts to "mak[e] history by unmaking preceding realities and significations" resides in their diagrammatic aspect. ${ }^{24}$ Scientists are deeply implicated in that history, but certainly, as I hope to have shown with my examples, never on their own.

\section{Acknowledgments}

Support from the Swiss National Foundation Sinergia Grant CRSII5_183567 "In the Shadow of the Tree: The Diagrammatics of Relatedness as Scientific, Scholarly, and Popular Practice" is gratefully acknowledged. A three-month fellowship at the DFG-Centre for Advanced Studies "Imaginaries of Force," University of Hamburg, in 2019 gave me opportunity to discuss some of the ideas that shaped this article. I also thank two anonymous referees for valuable advice and criticism.

24 Gilles Deleuze, Foucault, trans. Seán Hand (French ed. 1986; London: Continuum International Publishing Group, 20o6), 35. 